\title{
Development Employee Creativity in Work Place: Measurement the Role Transformational Leadership
}

\author{
Hasbiyadi, Nurlaley Razak
}

\begin{abstract}
Any organizations need creative employees who generate new ideas to develop product or process innovation. Observing the implications of leadership style, the study examines the role of transformational leadership in predicting employee creativity .A study was carried out using 240 employees as respondents. The findings indicate that leadership style can foster employee's creativity on work environment. The results also supported the hypothesis that leadership style enhances creative performance.
\end{abstract}

Keywords: Transformational, creativity and work environment.

\section{INTRODUCTION}

In times of highly competitive global economy, the survival of organizations depends on the sustainable innovation [1]. Idea generation can be regarded as an important stage in the organizational innovation process [2].

An organization or a company must be able to improve its competitiveness through a change, innovation and creativity in order to survive, thrive and grow in today's global crisis circumstances [3]. This requires a commitment and active role of all employees involving in the organization. Human resources are the main factor of the organizational life because the overall success of the organization heavily depends on the quality of its human resources [4]. One way to increase productivity is to increase the level of innovative thinking and creativity of employees. Employees who are more creative can find faster ways which can be used as solution to a problem [1].

Creativity is actually an effort of each employee to identify problems, think and use policies that exist in themselves. The process of creativity is involved effectively, both in quality and quantity [5]. Creativity is a potential which is very important and must be nurtured and developed in an employee. Creativity of a worker will support work productivity, and in turn it will improve work performance or performance of the company, so that the work efficiency and effectiveness ofthe company can be achieved. A creative individualist an individual who fully opens to all the resources, plays and cultivates himself or herself to seek alternative sources. However, It will sometimes be difficult for others to draw conclusions whether the creative

Revised Manuscript Received on October15, 2019

* Correspondence Author

Hasbiyadi*, Management Departement, STIEM Bongaya Makassar, Indonesia. Email: hasbiyadi@stiem-bongaya.ac.id

Nurlaley Razak, Management Departement, STIEM Bongaya Makassar, Indonesia. individualist "being serious or not being serious" in their behavior [6].

In recent transformational leadership, creativity studies has emerged as a strong predictor of employee creativity [7,8]. For example, mobilizes the necessary contextual resources for subordinates to exert creative behavior and transformational leadership engenders a supportive innovation climate (Junget al., 2003). However, very few studies have addressed the subject of creativity in the Indonesian and Indian context. For example, Tafsir et al. [9] has found significant impact transformational leadership on creativity climate in workplace and Gupta et al. [10] has found impact of leaders on employee creativity.

The company's success in facing competitive business is regarded as a state of creativity in the work environment which will positively affect the company's performance. High creativity of employees is one of the requirements to achieve a company's objectives (Akib and Dharma, 2004). This is a challenge for the management of the company that needs to seriously understand about the condition, thus the company must attempt to improve employee performance through improving the quality of human resources which contribute to the achievement of the goals and the viability of the company.

Leadership is one of the issues in the management which still becomes an interesting topic to be discussed nowadays. Both electronic and print media often feature opinion and discussion related to leadership. The leadership role is very strategic and important for achieving vision, mission, and goals of an organization and it is also one of the motives that drive people to always delve into the intricacies associated with leadership. The quality of a leader is often considered as the most important factor in the success or failure of the organization [11]. The success or failure of a business-oriented organizations and the public is usually perceived as the success or failure of the leaders. Therefore, the roles of leaders are very predominant so that the issue of leadership still interestingly attracts scholars' attention for their research in the field of organizational behavior. Schein [12] and Kouzes and Posner [13] argued that leaders have enormous influence on the success of the organization. Leaders play a key role in formulating and implementing the organization's strategy (Akib and Dharma, 2004).

Studies conducted Jaiswal and Dhar [14] reported that the creativity of employees increased if leaders accepted and displayed respect for cognitive differences and discrepancies.

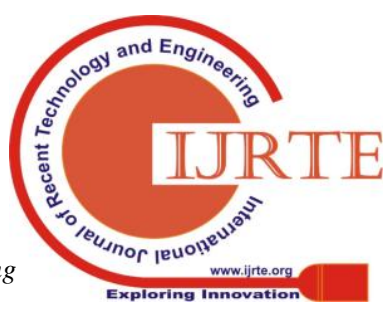


Similarly, when the leaders have strong encouragement towards creative tasks of employees, in turn this encouragement affects the performance of the workers themselves [15]. To consider the interaction between leaders and employees, high performance will become an integral part of the contribution which depends on both sides [15].

Employee performance cannot be separated from the role of leader. According to Bass [11], the top leadership role in contributing to the employees for achieving optimal performance is conducted through five ways: (1) the leader clarifies of what is expected from employees, in particular the goals and objectives of their performance, (2) the leader explains the way to meet these expectations, (3) the leader puts forward of the criteria in conducting evaluation of performance effectively, (4) the leader provides feedback if the employee has reached the target, and (5) the leader allocates rewards based on the achieved results.

One of the leadership theories that explain the important role of leaders in creating a conducive work environment is the Path Goal Theory propounded by Robert House [16] in which the theory says that leaders encourage higher performance by providing activities to influence subordinates so they believe that the results are worthwhile that can be achieved by using a serious effort. Universally applicable leadership produces inferior high level of performance and satisfaction. This theory stated that different situations require different leadership styles. Subordinates with internal locus of control will have higher job satisfaction using a participatory leadership style, while subordinates with external locus of control will have higher job satisfaction through a directive style.

Path Goal theory describes the behavior of directive leadership style, supportive style, participative style, style and trend orientation caregivers influence the expected performance. Thus, the leadership style affects the work performance and work achievement of the subordinates. By using one of the four leadership styles, a leader must try to influence the perceptions of subordinates and can motivate them in terms of clarity of their duties, achievement of goals, job satisfaction and effective implementation (Griffin, 1980).

A leader has the responsibility to carry out the duties and responsibilities thus the existence of the leader should know the whole organization. In turn, this condition can promote harmonious cooperation in the organization therefore a leader by using a specific leadership style plays a significant role in the success of the organization the leader leads in terms of directive, supportive, participative functions and achievement orientation for job satisfaction as well as organizational commitment and performance of subordinates.

Thus, based on the above description the hypothesis of this research can be formulated as follows:

H1 : Transformational leadership style has significant impact on the development of the creativity of workers

\section{MATH}

\section{A. Sample}

This study was conducted in Indonesia, surveying banking sectors. A total of 175 respondents from 6 companies returned the valid data, representing a response rate of $88 \%$. Among the respondents, $92 \%$ of them were educated in the level of university and diploma and 146 of them $(83.3 \%)$ were male and 29(16.7\%) were female. The mean of age was 30 ranging between 20 and 48 years old. The mean of working experience was approximately 3 years where a quarter of them have worked less than 3 years, and one-third of the have worked over ten years. The respondents performed different work functions including administration, human resource and marketing. In terms of job position, about 100 per cent were staff.

\section{B. Measures}

A post-experiment manipulation check was conducted to verify the intended leadership manipulation using the Indonesian version of the Multifactor Leadership Questionnaire (Avolio et al. 1999). Each item was completed on a 5-point Likert scale ranging from 1 (do not agree) to 5 (totally agree). A sample item representing transformational leadership was 'My leader seeks differing perspectives when solving problems'.

To measure employee creativity, we adopted a four-item scale used by Tierney and Farmer [17]. This scale was originally developed by Tierney et al. [15] to assess the creative performance of the employees through their supervisors. A sample item was "This subordinate identifies opportunities for new ways of dealing with work" $c_{c}=$ 0.93 ).Following recent creativity studies, we controlled for employees' age, gender, education and experience due to their confound relation that may lead to task domain expertise or knowledge, which in turn could play role in determining creative performance [7]. The study also controlled for supervisors' age, gender and education.

Analysis of the relationship between the constructs of the variables is done in two stages, namely (i) Measurement Evaluation Model (outer model) and (ii) Testing of Structural Model (Inner model). Outer model used to measure the construct validity and reliability construct. Validity testing is done in two ways, namely convergent and discriminant validity. validity. Convergent validity is construct validity testing using the load factor (factor loading) and extract the square root of the average variance (square root of the average variance extracted (AVE)). An indication is valid if the load factor greater than 0.5 and is intended to construct AVE $>0,50$ [18]. Meanwhile, discriminant validity, construct validity was tested by measuring V AVE and compared with the correlation between constructs. An indication is valid if it has the highest load factor to construct the intended load factor compared to other constructs. In other words, $\sqrt{ }$ AVE $>$ correlation between constructs [18]. Reliability testing is done by measuring the composite reliability of each item or construct. Or construct an item is said to be reliable if Cronbachs alpha $>0.60$ and reliability of composite $>0.70$ $[18,19]$. Testing Structural Model (Inner Model) made after the model is estimated to meet criteria external model. Testing is done by measuring the structural model R-Square on the construct. R-Square shows the coefficient of determination, namely the extent to which a construct capable of explaining the model. Further testing the hypothesis calculation $\mathrm{T}$ Statistics. The results of these calculations can be used to test the significance of the construct. If $\mathrm{a}=5 \%, \mathrm{t}=1.96$ and T-criteria Statistics> 1.96 was considered significant then constructs $[18,19]$. 


\section{RESULT AND DISCUSSION}

Firstly, Rosing et al [20] stated that leadership research has to move away from examininggeneral leadership styles but it should be designed to assess other leadership styles using a specific situation. By bringing together leadership styles and creativity techniques, this study can provide a next step towards a better understanding of the interaction between more general leadership style behaviors that occur across situations and specific creativity techniques that are employed in a specific situation. On the other hand, leadership styles refer to more relational and interpersonal behaviors (e.g. Encouragement and trust) and the creativity techniqueservesas a concrete strategy in terms of the sequence of steps which are required by a leader to promote creativity.

Table 1. Latent Variables Correlation Hypothesis

\begin{tabular}{|l|r|r|r|r|r|r|r|r|r|r|r|r|}
\hline & X.A & X.B & X.C & X.D & X & Y.A & Y.B & Y.C & Y.D & Y.E & Y & Y.F \\
\hline X.A & $\mathbf{0 . 9 5 1}$ & & & & & & & & & & & \\
X.B & 0.545 & $\mathbf{0 . 7 0 9}$ & & & & & & & & & & \\
X.C & 0.315 & 0.542 & $\mathbf{0 . 7 1 9}$ & & & & & & & & & \\
X.D & 0.652 & 0.432 & $\mathbf{5 4 7 7}$ & $\mathbf{0 . 7 2}$ & & & & & & & & \\
X & 0.678 & 0.731 & 0.751 & 0.76 & $\mathbf{0 . 8 0 9}$ & & & & & & & \\
Y.A & 0.236 & 0.807 & 0.277 & 0.15 & 0.653 & $\mathbf{0 . 9 4 3}$ & & & & & & \\
Y.B & 0.241 & 0.247 & 0.377 & 0.25 & 0.396 & 0.154 & $\mathbf{0 . 9 8 2}$ & & & & & \\
Y.C & 0.567 & 0.038 & 0.009 & 0.11 & 0.028 & 0.069 & 0.049 & $\mathbf{0 . 9 6 2}$ & & & & \\
Y.D & 0.301 & 0.724 & 0.414 & -0.08 & 0.702 & 0.692 & 0.680 & 0.101 & $\mathbf{0 . 7 3 3}$ & & & \\
Y.E & 0.036 & 0.117 & 0.001 & 0.01 & 0.083 & 0.189 & -0.081 & 0.051 & 0.075 & $\mathbf{0 . 9 4 3}$ & & \\
Y & 0.504 & 0.793 & 0.515 & 0.06 & 0.818 & 0.715 & 0.664 & 0.134 & 0.814 & 0.146 & $\mathbf{0 . 8 8 9}$ & \\
& 0.639 & 0.522 & 0.462 & 0.53 & 0.632 & 0.258 & 0.242 & 0.036 & 0.342 & 0.069 & 0.648 & $\mathbf{0 . 7 6 0}$ \\
Y.F & 4 & 1 & 0.9 & 2 & 7 & 9 & 5 & 4 & 0.069 & \\
\end{tabular}

Results of this study show that the transformational leadership style can provide effect to increase the creativity of the workers in the workplace. These results are consistent with the results of the study conducted by Seltzer and Bass [21] which claimed that a leader stimulates creativity and encourages subordinates to find new approaches to old problems. Also according to Bass [22] a leader encourages every employee to think about the relevance of taste, value systems, beliefs, expectations and organizational forms that exist today. Workers are also supported to innovate and be creative in solving problems in order to develop self-efficacy, and they are encouraged to set goals or targets encountered. To assess the creativity, we adopted Couger [23], Amabile [24], Nonaka and Takeuchi [25] with 6 dimensions (vertical cooperation, lateral cooperation, autonomy, respected, work Situation, harmonious).

\section{A. Hypothesis Analysis.}

Hypothesis testing is done as follows:

- Measurement Evaluation Model External.

Ratings measure the external model is to see whether the indicators used in the study are valid and reliable or not. Tests carried out to ascertain the validity of any indication that the construct is able to form legally addressed.

Another method for discriminant validity were seeing the square root of AVE as shown in Table 1. The recommended value is above 0.5. An indicator declared invalid if it has the highest loading factor to construct the intended loading factor compared to the other constructs. Display table 1 shows all constructs transformational leadership and creativity has value above $0.5 \mathrm{AVE}$. This indicates that the instructions have been valid in the formation of constructs intended. Meanwhile, the correlation between the latent variables are shown in below.

Construct X (transformational leadership) have the $\mathrm{AVE}=0.6594$; then V0.5163 $=0.7185$. Meanwhile, the correlation between $\mathrm{Xi}$ (transformational leadership) with another block, 0.8093 ( $\mathrm{Y}=$ creativity), 0.8891 (YA = Lateral Cooperation), 0.9432 ( $\mathrm{YB}=$ Vertical Cooperation), at 0.982 $(\mathrm{YC}=$ Respected $)$, at $0,9629(\mathrm{YD}=$ Autonomy $), 0,7332(\mathrm{YE}$ $=$ Work Situation), 0.943(YF $=$ Harmonious) 0.7601. This means that the discriminant validity are met

\section{B. Reliability Test}

Reliability testing is done by looking at the reliability of the composite of indicators that measure the constructs of block. The results of the reliability of composite above 0.7 indicates a satisfactory value. The output value of the reliability of composite displayed in the table. Value outputs displayed for all constructs are above 0.7 indicating that all constructs in the model estimates of discriminant validity criteria are met.

\section{Model Internal}

The following table shows the size of the validity and reliability of the hypothesis .

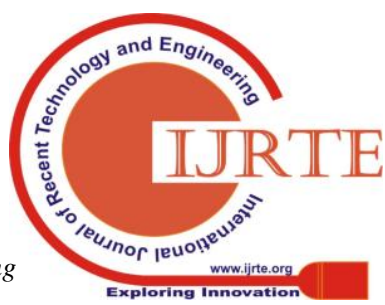


Table 2. Average Variance Extracted (AVE), Composite Reliability, Cronbach Alpha And R Square Hypothesis

\begin{tabular}{|l|c|r|r|r|r|r|}
\hline & AVE & \multicolumn{1}{c|}{$\begin{array}{c}\text { AVE } \\
\text { SQ }\end{array}$} & $\begin{array}{c}\text { Composite } \\
\text { Reliability }\end{array}$ & R Square & $\begin{array}{c}\text { Cronbach } \\
\text { Alpha }\end{array}$ & Communality \\
\hline X.A & 0.9060 & 0.9518 & 0.9507 & 0.4600 & 0.8963 & 0.9060 \\
X.B & 0.5036 & 0.7096 & 0.8864 & 0.8684 & 0.8486 & 0.5036 \\
X.C & 0.5181 & 0.7198 & 0.8414 & 0.5640 & 0.7625 & 0.5181 \\
X.D & 0.6824 & 0.8261 & 0.8207 & 0.7818 & 0.6528 & 0.6147 \\
X & 0.6594 & 0.8120 & 0.8535 & 0.0000 & 0.8220 & 0.2594 \\
Y.A & 0.8897 & 0.9432 & 0.9416 & 0.5115 & 0.8764 & 0.8897 \\
Y.B & 0.9644 & 0.9820 & 0.9819 & 0.4414 & 0.9631 & 0.9644 \\
Y.C & 0.9272 & 0.9629 & 0.9622 & 0.0180 & 0.9216 & 0.9272 \\
Y.D & 0.5379 & 0.7334 & 0.8231 & 0.8354 & 0.7137 & 0.5379 \\
Y.E & 0.8893 & 0.9430 & 0.9414 & 0.0215 & 0.8764 & 0.8893 \\
Y & 0.6306 & 0.8802 & 0.8085 & 0.6707 & 0.7725 & 0.2306 \\
Y.F & 0.5777 & 0.7601 & 0.8706 & 0.4209 & 0.8099 & 0.5777 \\
\hline
\end{tabular}

Table above shows the R Square to construct $\mathrm{Y}=0.6707$ which means that Xi (transformational leadership) could explain $67.07 \% \%$ variance of Y (creativity). While the Goodness of Fit (GOF) is done by multiplying the square root of the square $\mathrm{R}$ square with the square root of the average value of communality $=\mathrm{VR} 2 \times \mathrm{V}$ communality $=\mathrm{V} 0.8421 \times \mathrm{V} 0.6549=$ 0.5514. The test hypothesis is shown in table below.

Table 3. T Counts for Testing Hypotheses

\begin{tabular}{|c|r|r|r|r|r|}
\hline & $\begin{array}{c}\text { Original } \\
\text { Sample (O) } \\
(\mathrm{O})\end{array}$ & $\begin{array}{c}\text { Sample } \\
\text { Mean (M) } \\
(\mathrm{M})\end{array}$ & $\begin{array}{c}\text { Standard } \\
\text { Deviasi } \\
\text { (STDEV) }\end{array}$ & $\begin{array}{c}\text { Standard } \\
\text { Error } \\
\text { (STREER) }\end{array}$ & $\begin{array}{r}\text { T Statistics } \\
\text { (O/STERR) }\end{array}$ \\
\hline Leader -> CH & 0.6782 & 0.6781 & 0.0355 & 0.0355 & 19.0958 \\
Leader -> IS & 0.9319 & 0.9323 & 0.0064 & 0.0064 & 145.2905 \\
Leader -> IM & 0.7511 & 0.7545 & 0.0279 & 0.0279 & 26.9556 \\
Leader -> IC & 0.4721 & 0.4725 & 0.0384 & 0.0384 & 12.2352 \\
Leader->Creat & $\mathbf{0 . 8 1 8 9}$ & $\mathbf{0 . 8 2 1 9}$ & $\mathbf{0 . 0 1 7 4}$ & $\mathbf{0 . 0 1 7 4}$ & $\mathbf{4 7 . 0 9 9 3}$ \\
Creat -> VL & 0.7152 & 0.7138 & 0.0319 & 0.0319 & 22.3958 \\
Creat-> LV & 0.6644 & 0.664 & 0.0413 & 0.0414 & 16.2091 \\
\hline Creat -> RP & 0.1342 & 0.1348 & 0.0016 & 0.0621 & 2.2355 \\
Creat -> AM & 0.9174 & 0.9128 & 0.0099 & 0.0099 & 92.7475 \\
Creat -> HM & 0.1466 & 0.1426 & 0.0794 & 0.0794 & 1.846 \\
Creat -> WS & 0.6488 & 0.655 & 0.0405 & 0.0405 & 16.0048 \\
\hline
\end{tabular}

Show table above the count of $\mathrm{T}$ XI to $\mathrm{Y}$ is 47.099 , which is well above the expected value; 1.96. Thus, there exists a significant influence $\mathrm{X} \mid$ (transformational leadership) to Y (creativity).

Equations based on the original sample (original sample) is as follows; $\mathrm{Y}=0.6707 \mathrm{Xi}$. Calculate the value of another $\mathrm{T}$ is $\mathrm{T}$ count among dimensional construct that addressed all of which show a significant value.

The figures shown in the figure above shows the $\mathrm{T}$ counting. Therefore, this figure can also be used as a test of validity for each indicator has a value estimate of 1.96 in shaping constructs intended. The formulation of hypothesis testing 1: i. There is a simple and positive relationship between transformational leadership with the creativity shown by the table $\mathrm{r}=0.6707$

ii. Transformational Leadership (Xi) can explain $67.07 \%$. climate variance creativity (Y).

iii. There exists significant relationship between transformational leadership (xi) to creativity (Y). This is shown by the $\mathrm{T}$-test $\mathrm{Xi}=47.099$; greater than the expected value, 1.96; significant level is 0.05 .

iv. The regression equation between transformational leadership with creativity is $\mathrm{Y}=0.8189 \mathrm{X}]$, which intends every stage of changes that apply to the transformational 
leadership will lead creativity change $=0.8189$.

The increasing importance of employee creativity in all types of business organizations has fostered researchers to search out the mechanisms that stimulate creativity among employees. There is a consistent gap in the literature about what transformational leadership style effect on the process of predicting employee creativity through various antecedents [26]. The study empirically supports that an employee's perception about his/her leader's transformational way of leading, supportive innovation climate and beliefs about his/her ability to perform creatively influence their creative performance. In line with recent studies [6], it was revealed that transformational leaders promote creativity among their sub-ordinate employees. Extending the findings of Gupta et al. [10], this study found a positive relationship between transformational leadership and individual creativity and consistent to findings by Gumusluoglu and Ilsev [8]. Thus, while demonstrating the transformational leadership in a collective setting, leaders are able to provide what their subordinates always seek from them, i.e., support, assistance, attention and suggestion (Sinha,2008).

The results showed that there is a significant and positive relationship between transformational leadership with the employee creativity in the work environment. The results obtained showed that the correlation coefficient is 0.6707 or $67.07 \%$. These findings indicate that the improvement of creativity of employees in the work environment highly requires transformational leadership roles. The findings are also in line with the findings of previous studies conducted by Heermann and Felfe [27] that the creativity of employees increased if leaders accepted and demonstrated respect for cognitive differences and contradictions. Similarly, when leaders have a strong encouragement to enhance creative tasks of workers, it can ultimately affect the performance of the workers themselves.

An organization can be successful if creativity can be well implemented in the organization. Organizations that have a leader who cannot provide opportunity for employees to use and develop creativity skills will not become a successful organization. Therefore, a way to transform organizations uncomfortable is indispensable. A good leader is not a leader who just wants to improve profitability, but the leader should be able to deal with the work environment positively so that employees can be proud of becoming part of it. This notion is claimed by Amabile et al. [28] that the behavior of a leader is a key factor in the development of a work environment that determines the climate of creativity among employees. The transformational leadership styles used in this study have supported the creative in work environment. The findings of this study show that the leaders are always trying to develop creativity in the work environment because of several reasons. Firstly, they provide credence to every employee to perform any duties and responsibilities properly. Secondly, the leaders fully trust their employees in order to complete duties and responsibilities entrusted to the employees so that they understand their potentials in order to work better as demanded. Thirdly, the leaders deliver and provide an understanding to their employees about the organization's vision and mission that should be understood equally by the employees. Next, the leaders assign tasks and responsibilities in accordance with the guidance and they will see the progress of work by evaluating the tasks. Finally, the leaders provide a huge opportunity to their employees to use their potential and creativity in the workplace. This research is in line with the results of the study Shin [29] transformational leadership positively related to the creative climate of workers, "conservation" followers of a value, strengthening relationships with leaders, and having an intrinsic motivation to contribute to transformational leadership and conservation leadership partly contributes to transformational leadership in the creative climate. The same study was done by Bass and Avolio (1994) who concluded that workers learned to solve problems in their own creative and innovative ways.

The leaders attempt to increase the process of developing creativity of workers with creative potential of its employees by providing a new task and assume certain tasks so that they are more confident. They also encourage workers to develop employees' critical and innovative minds although the employees do not have to produce new products, but other results that can be also useful to other people. Additionally, leaders entrust the work carried out by their subordinates in their own way, but it should be in accordance with work safety procedures. The confidence is expected to be developed by employees so that they can be more confident and more critical in the workplace. This finding is supported by the findings of a study conducted by Seltzer and Bass [21] where a leader stimulated creativity and encouraged subordinates to seek new approaches to old problems. In addition, Bass [22] claimed that a leader supports every employee to think about the relevance of taste, value systems, beliefs, expectations and organizational forms that exist today. Employees are also supported to innovate in solving problems and developing their ability to be creative, and they are encouraged to set goals or targets faced. Although the results of this study stated that transformational leadership influence on the climate of creativity, but the research can be developed by trying to use organization culture or the other leadership style.

\section{CONCLUSION}

In conclusion, this study attempted to examine the role of trans-formational leadership in predicting creativity among employees of banking industry. The findings provide suggestion for stake holder to consideration attention increase to employees creativity, because that employees receive support from their organizations and their immediate supervisors, in view of performing creatively.

\section{REFERENCES}

1. Mumford, M. D. and B. Licuanan (2006). Leading For Innovation: Conclusions, Issues, And Directions, Leadership Quarterly 15 (1), 163-171.

2. Litchfield, R. C. (2008). 'Brainstorming reconsidered: a goal based view', Academy of Management Review, 33, pp. 649-668.

3. Dharma, S. (2005). Manajemen Kinerja. Jakarta: Pustaka Pelajar, Radjawali Press.

4. Dragoni, L., (2005). Understanding The Emergence Of State Goal Orientation In Organizational Work And Groups: The Role Of Leadership And Multilevel Climate Perceptions. Journal.Application.Psychology.90 (6), 1084. 
5. Judge, T. A. and R. F. Piccolo (2004). 'Transformational and transactional leadership: a meta-analytic test of their relative validity', Journal of Applied Psychology, 89, pp. 755-768.

6. Wang, C.J., Tsai, H.T., Tsai, M.T., (2014). Linking Transformational Leadership And Employee Creativity In The Hospitality Industry: The Influences Of Creative Role Identity, Creative Self-Efficacy, And Job Complexity. Tourism. Management, 40 (1),79-89.

7. Gong, Y., Huang, J.C., Farh, J.L., (2009). Employee learning orientation,transformational leadership, and employee creativity: the mediating role of employee creative self-efficacy. Academi.Management.Journal. 52 (4), 765-778

8. Gumusluoglu, L., Ilsev, A., (2009). Transformational leadership, creativity, and organizational innovation. Journal of Business Research 62 (4), 461-473.

9. Tafsir. Muhammad. et. al (2016). The Role of Transformational Leadership on Creativity Climate Development in Workplace. Humanistic Management Network, Research Paper Series No. 46/15

10. Gupta, V., Singh, S., Kumar, S., Bhattacharya, A., (2012).Linking leadership to employee creativity: a study of Indian R\&D laboratories.The Indian Journal of Industrial Relations 48(1), 120-136.

11. Bass, B. (1996). A New Paradigm for Leadership: An Inquiry into Transformational Leadership.Alexandria.Virginia: U.S. Army Research Institute for the Behavioral and Social Sciences.

12. Schein, Edgar H. (1992). Organizational Culture and Leadership. San Francisco: Jossey-Bass Publisher.

13. Kouzes, J., Posner, B. (2007).The Leadership Challenge(4nd ed.). San Francisco, CA: Jossey-Bass

14. Jaiswal, N.K, Dhar. R.L.(2015). Transformational leadership, innovation climate, creative self-efficacy and employee creativity: A multilevel study. International Journal of Hospitality Management 51 (2015) 30-41

15. Tierney, P., Farmer, S., Graen, G. (1999). An Examination Of Leadership And Employee Creativity: The Relevance Of Traits And Relationships. Personnel Psychology, 52(1),591-621.

16. Yukl, G. (2000). Leadership in Organizations. $4^{\text {th }}$ ed. Englewood Cliffs, NJ: Prentice Hall

17. Tierney, P., Farmer, S.M., (2011). Creative self-efficacy development and creative performance over time.Journal Application Psychology.96 (2), 277-293

18. Hair, J. F., Hult, G. T. M., Ringle, C. M., \& Sarstedt, M. (2013).A Primer on Partial Least Squares Structural Equation Modeling.Thousand Oaks: Sage.

19. Ghozali (2014).SEM Metode Alternatif dengan Partial Least Square (Edisi 2). Semarang: BP-Universitas Diponegoro.

20. Rosing, K., M. Frese and A. Bausch (2011). Explaining The Heterogeneity Of The Leadership-Innovation Relationship: Ambidextrous Leadership. Leadership Quarterly, 22, 956-974.

21. Seltzer, J., Bass, B. M. (1990).Transformational Leadership: Beyond Initiation and Consideration.Journal of Management, 16(4), 693-703.

22. Bass, B. M. (1985). Leadership and Performance Beyond Expectations. New York: Free Press.

23. Couger, J.D. (1996). Creativity and lnnovation in lnformation System Organization.Danvers MA: Boyd and Fraser Publishers.

24. Amabile, T.M. (1982), "Social psychology of creativity: a consensual assessment technique", Journal of Personality and Social Psychology, Vol. 43 No. 5, pp. 997-1013.

25. Nonaka, Ikurjiro and Hirotaka Takeuchi (1995).The Knowledge-Creating Company, Oxford University Press.

26. Kumar, Neeraj and Lochan D, Rajib (2015).Transformational leadership, innovation climate, creative self-efficacyand employee creativity: A multilevel study. International Journal of Hospitality Management 51 (2015) 30-41

27. Heermann, D, Felfe, J. (2014). Effects of Leadership Style, Creativity Technique and Personal Initiative on Employee Creativity.British Journal of Management, 25(2), 209-227.

28. Amabile, T.M., Barsage, S.G., Mueller, J.S., \& Staw, B.M. (2005).Affect and Creativity at Work.Administrative Science Quarterly,50, 367.

29. Shin, Sun Jae (2006). The Leadership Role in Korean Organization.Enterpreunership Journal.6

\section{AUTHORS PROFILE}

Hasbiyadi is from the Management Departement, STIEM Bongaya Makassar, Indonesia.
Nurlaley Razak is from the Management Departement, STIEM Bongaya Makassar, Indonesia. 